\title{
Relationships between Flagellin Genes Variants of Salmonella enterica Serovar Typhi and Severity of Illness from Acute and Carriers State of Typhoid Fever
}

\author{
Muhammad Sabir ${ }^{1,3}$, Ressy Dwiyanti ${ }^{1,3}$, Andini Febrianty ${ }^{1,3}$, Nataniel Tandirogang ${ }^{4}$, Yadi Yasir ${ }^{4}$, Masyudi Amir $^{4}$, \\ Andi R Sultan ${ }^{3}$, Nur Indah Purnamasari', Muhammad Reza Primaguna ${ }^{3}$, Munawir Muhammad ${ }^{3}$, Mochammad Hatta, ${ }^{3,{ }^{*}}$ \\ ${ }^{1}$ Department of Microbiology, Faculty of Medicine, Tadulako University, Palu, Indonesia \\ ${ }^{2}$ Department of Microbiology, Faculty of Medicine, Haluoleo University, Kendari, Indonesia \\ ${ }^{3}$ Molecular Biology and Immunology Laboratory for Infectious Diseases, Faculty of Medicine, Hasanuddin University, Makassar, Indonesia \\ ${ }^{4}$ Department of Microbiology, Faculty of Medicine, Mulawarman University, Samarinda, Indonesia \\ *Corresponding author: hattaram@indosat.net.id
}

Received June 20, 2014; Revised August 18, 2014; Accepted September 09, 2014

\begin{abstract}
Background: The molecular pathogenesis of severity of illness in typhoid fever is poorly understood. Previous studies have found a direct relationship between flagellar function as determined by motility, and invasiveness in Salmonella species. A previous study revealed that the Hj flagellin genes association of decreased severity of illness, motility and invasiveness of bacteria and compared with Hd flagellin genes. However the role of flagella in in-vivo virulence however remains more controversial. Objectives: In an attempt to elucidate the mechanisms behind severity of typhoid fever in relation with flagellin genes variation, we conducted a prospective and retrospective study to describe the clinical sign \& symptoms, flagellin genes variations among from acute and carrier state of typhoid fever patients. Methods: 187 genomic DNA of S. typhi strains from culture of 141 acute typhoid fever and feces of 46 carriers state of typhoid fever who enrolled in several primary health care and hospitals in endemic area of Central Sulawesi, Indonesia. All isolate were examine the $\mathrm{Hd}, \mathrm{Hj}$, z66 and z66 Ind of flagellin genes by Polymerase Chain Reaction (PCR). Results: The results of this study revealed that predominant in severity of illness in both acute and carriers state of typhoid fever belong $\mathrm{Hd}^{+}$and $\mathrm{Hd}^{+} \mathrm{z} 66 \mathrm{Ind}^{+}$in endemic area of Indonesia. Conclusion: $\mathrm{Hd}^{+}$and $\mathrm{Hd}^{+} \mathrm{z} 66 \mathrm{Ind}^{+}$flagellin gene variation are related to clinical severity of acute typhoid fever.
\end{abstract}

Keywords: flagellin genes, severity of illness, Salmonella enterica serovar Typhi, acute and carrier state

Cite This Article: Muhammad Sabir, Ressy Dwiyanti, Andini Febrianty, Nataniel Tandirogang, Yadi Yasir, Masyudi Amir, Andi R Sultan, Nur Indah Purnamasari, Muhammad Reza Primaguna, Munawir Muhammad, and Mochammad Hatta, "Relationships between Flagellin Genes Variants of Salmonella enterica Serovar Typhi and Severity of Illness from Acute and Carriers State of Typhoid Fever.” American Journal of Infectious Diseases and Microbiology, vol. 2, no. 4 (2014): 74-80. doi: 10.12691/ajidm-2-4-1.

\section{Introduction}

Typhoid fever is a systemic infection caused by the bacterium Salmonella enterica subspecies enterica serotype Typhi (S. typhi). The disease causes much morbidity and mortality in developing countries and is characterized by prolonged fever, bacterial growth in cells of the reticuloendothelial system, and significant inflammation of the lymphoid organs of the small intestine. Symptoms of typhoid fever are characterized by fever (90-100\%), coated tongue (96.3\%), malaise (93.8\%), headache (83.8\%), nausea (27.5\%), constipation (12.5\%), abdominal distention (12.5\%), diarrhea (11.3\%), and melena (8.8\%) [1]. Recognition of these symptoms important in preventing the delayed diagnosis of typhoid fever that can lead to severe typhoid infections such as such as extra-intestinal infectious on central nervous system, cardiovascular system, pulmonary system, bone, joints, hepatobiliary system, and genitourinary system [2].
Salmonella enterica serovar Typhi can colonize the gallbladder and persist in an asymptomatic carrier state that is frequently associated with tbhe presence of gallstones [3]. The asymptomatic, chronic carrier state of $S$. typhi occurs in the bile-rich gallbladder, is frequently associated with the presence of cholesterol gallstones, and does not subside with antibiotic treatment [3], yet the mechanism behind progression and severity from infection to persistence remains unknown. Also, the pathogenesis of intestinal perforation in patients with typhoid fever is poorly understood with respect to the host and bacterial factors involved [4].

Flagella are expressed on the surface of Salmonella cells. They consist of a basal body embedded in the cell membrane, a central rod attached to a hook which in turn attaches to a helical filament made up of polymerised units of flagellin protein $[5,6]$. Rotation of the basal body motor results in movement of the filament which facilitates cell motility. Most Salmonella have two distinct flagellin genes fliC and $\mathrm{fljB}$, but express only one at a time, 
switching between them at a rate of $10^{-3}-10^{-5}[7,8]$. This process, known as phase variation, is present in four subspecies of S. typhi [9].

Some early studies have suggested a direct relationship between flagellar function as determined by motility, and invasiveness in Salmonella species. However the role of these flagellar genes to to clinical severity is still controversial. Previous study revealed that the Hj flagellin genes association of decreased severity of illness, motility and invasiveness of bacteria and compared with $\mathrm{Hd}$ flagellin genes [10]. Therefore we conducted a study to assess the relationships between clinical symptoms and flagellin genes variant in acute and carriers state of typhoid fever. A secondary aim of the study was to identify flagellin genes variant of $S$. typhi in gall bladderrelated chronic carriage of typhoid fever.

\section{Materials and Methods}

\subsection{Clinical Specimens}

A total of 671 clinical suspicion of typhoid fever and 924 ex-patients were included in the study. S. typhi isolates were obtained from blood cultures from 141 acute febrile patients with clinical suspicion of typhoid fever presented at several primary health care centers and hospitals in around Palu District in Central Sulawesi and 46 genomic DNA of feces from home visit of ex-patients at least one year before. All isolates were confirmed to be serovar Typhi by biochemical testing and nested PCR [11].

The mean age of the acute patients and carriers state was 31.2 years (range, 10-59) and 30.7 (range, 9-61), respectively and the male to female ratio of the acute patients and carriers state was 1:1. Mean body temperature of acute patients on admission is $38.4^{\circ} \mathrm{C}$ (range, 37.8$39.4^{\circ} \mathrm{C}$ ) while on carrier state, healthy individuals who has history of typhoid fever with $38.3^{\circ} \mathrm{C}$ (range, $37.8-39.1^{\circ} \mathrm{C}$ ). A mean duration of illness of acute patients is 5.9 days (range, 4-10) and carrier state on admission history is 6.6 days (range, 5-9), respectively. The severity of the case was recognized by the present of sign/symptoms like stupor, melena and abdominal perforation on typhoid patient. The clinical information had been collected prospectively for acute cases and retrospectively for carrier states using a structured questionnaire that was completed by the responsible physician or nurse.

\subsection{Ethical Considerations}

The project was approved by the review boards of the participating institutes and informed consent was obtained from all participants or their parents/guardians.

\subsection{Blood Culture}

Five milliliters of freshly collected blood was placed in $15 \mathrm{~mL}$ of Ox bile broth (Merck, Darmstadt, Germany) and incubated for 24 hours at $37^{\circ} \mathrm{C}$. One milliliter of this culture was then plated on Salmonella Shigella (SS) agar (Oxoid, Basingstoke, United Kingdom), incubated for 24 hours at $37^{\circ} \mathrm{C}$, and examined for growth. If growth was present, individual colonies were examined by Gram staining and identification of the bacteria was performed after subculturing on SS agar by biochemical testing with the triple sugar iron test, sulfide indole motility, methyl red Voges' Proskauer reactivity, citrate consumption, urease and decarboxylase activity, and carbohydrate fermentation of glucose, lactose, mannitol, sucrose, and arabinose [12,13].

\subsection{Serologic Analysis}

The Widal test with $\mathrm{O}$ antigen produced by Murex Biotech Ltd., Dartford, United Kingdom was performed and interpreted according to routine laboratory procedures. Briefly, two-fold serial dilutions $(1: 20-1: 1280)$ of the serum sample were prepared. One drop ( $25 \mathrm{ul})$ of the $\mathrm{O}$ antigen suspension was added to each tube containing the diluted sample. Antigen and serum were mixed and incubated at $50^{\circ} \mathrm{C}$. Tubes were checked for agglutination after $4 \mathrm{hr}$. According to routine diagnostic criteria, a titer $\geq$ 1:320 was considered positive for the samples tested in Indonesia.

\subsection{Preparation of DNA}

DNA was extracted from freshly collected culture of $S$. typhi and stool samples according to the diatomguanidinium isothiocyanate (GuSCN) method. For the extraction of DNA from culture, a freshly single colony of S.typhi sample was mixed with $900 \mathrm{uL}$ of lysis buffer (50 $\mathrm{mM}$ Tris-HCl, 5.25 M GuSCN, $20 \mathrm{mM}$ EDTA, 0.1\% Triton X-100) and centrifuged at $12,000 \times g$ for 10 minutes. For the preparation of DNA from feces, a stool sample with a volume of approximately $100 \mathrm{uL}$ was attached to a cotton swab, suspended in $1 \mathrm{~mL}$ of sterile water, vortexed vigorously, and centrifuged at 1,000 rpm for 5 min. To obtain the DNA, samples were lysed by incubation for 15 minutes at $18^{\circ} \mathrm{C}$ and $20 \mathrm{uL}$ of diatom suspension was added. The diatom containing the bound DNA was sedimented by centrifugation at $12,000 \times \mathrm{g}$ for 15 seconds. The diatom pellet was washed with washing buffer (5.25 M GuSCN in 0.1 M Tris-HCl, pH 6.4), rinsed with $70 \%$ ethanol and acetone, and dried by incubation at $56^{\circ} \mathrm{C}$ for 10 minutes. The pellet was mixed with 60 uLof10 mM Tris-HCl, pH 8.0, 1 mM EDTA buffer and the DNA was eluted by incubation at $56^{\circ} \mathrm{C}$ for 10 minutes. After sedimentation of the diatom by centrifugation, the supernatant was collected and stored at $-20^{\circ} \mathrm{C}$ until PCR was performed [14]. All these PCRs should work clearly on genomic DNA template from the diatom-guanidinium isothiocyanate (GuSCN) extraction method.

\subsection{Amplification of Flagellin Genes}

The fliC primers set for the fliC genes amplification, which will give a result of around $1500 \mathrm{bp}$ for the $\mathrm{H}$ :d antigen or about 200 bp smaller for the H:j antigen. The final set is for the z66 antigen, which will give a product of about 1500 bp if the strains are z66+, and will give no result if they are z66[14]. Amplification of fliC gene was performed using primers: fliC F: TTAACGCAGTAAAGAGAG and fliC_R: ATGGCACAAGTCATTAATAC and produce a $1521 \mathrm{bp}$ product for the $\mathrm{d}$ allele and a $1273 \mathrm{bp}$ product for the $\mathrm{j}$ allele. Amplification of the flj $^{\mathrm{z} 66}$ was performed as previously described using z66Flag_F: ATGGCACAAGTCATCAATAC and z66Flag_R: TTAACGCAGCAGAGACAGTAC. Control PCR amplicons from the aroC gene were produced using primers aroC for: CCTGGCACCTCGCGCTATAC and 
aroC rev: CCACACACGGATCGTGGCG. Primers position on chromosome fliC_F 2011173 and fliC_R 2012674; aroC_F 2450480 and aroC_R 2449674. The other primers are on a plasmid. Cycles is an initial denaturation at $94^{\circ} \mathrm{C}$ for $1 \mathrm{~min}, 30$ cycle at $94^{\circ} \mathrm{C}$ for $30 \mathrm{~s}$, $57^{\circ} \mathrm{C}$ for $30 \mathrm{~s}$, and $72^{\circ} \mathrm{C}$ for $2 \mathrm{~min}$, flowed by an extension step of $72^{\circ} \mathrm{C}$ for $2 \min [14]$.

For z66Ind primer set designated Ind-F : 5' ATG TCG GAA ATC AAC CGT ATC T 3' and Ind-R:5' CAG GCC GTC AAC CTG AGA C 3' were selected for the specific amplification of a 597 bp segment of the Ind gene. The PZ66-A and PZ66-B primers are located in the central region of the z66 gene that is largely deleted in the Ind gene and the primers Ind-F and Ind-R are located in the 5' and 3 ' portion of the Ind gene that shows homology with the z66 gene, but these primers are chosen such that the number of mismatches with this gene is too high to warrant efficient amplification of the z66 gene [1,15]. The Ind-specific PCR was performed with after an initial denaturation at $94^{\circ} \mathrm{C}$ for $2 \mathrm{~min}$, for 35 cycles at $94^{\circ} \mathrm{C}$ for $30 \mathrm{~s}, 55^{\circ} \mathrm{C}$ for $30 \mathrm{~s}$, and $72^{\circ} \mathrm{C}$ for $1 \mathrm{~min}$, followed by an extension step of $72^{\circ} \mathrm{C}$ for $5 \mathrm{~min}$. [1].

\subsection{Statistical Analysis}

All statistical calculations were performed using the EPI-Info version 6.0 and computer program SPSS (Statistical Package for the Social Science; SPSS, Chicago, IL, USA) computer package to determine which acute and carrier state of flagellin genes were associated with an increased risk for having severity of typhoid fever. Risk factors were first identified by univariate analysis. Variables that contained more than two categories were grouped into fewer categories by combining categories showing an identical risk. A multivariate logistic regression analysis was then performed to identify which of the potential risk factors (i.e. with $\mathrm{p}<0.05$ ) remained independently associated with severity of illness.

\section{Results}

\subsection{The Comparison Clinical Symptoms between Acute and Carrier State of Typhoid Fever}

In Table 1 revealed that most of clinical symptoms in both acute and carrier state are coated tongue, malaise and headache in both acute and carriers state of typhoid fever (98.5\%, 100\%, 93.6\% vs 97.8\%, 100\%, 84.8\%, respectively). No significant difference was found between carrier state and acute typhoid fever ( $\mathrm{p}>0.05)$. Other clinical symptoms are apathy, nausea, constipation, abdominal distention in acute state were found $13.5 \%, 13.5,5.7 \%$ and $5.7 \%$ in acute of illness, respectively, while these clinical symptoms in carrier state were found $8.7 \%, 23.9 \%$, $8.6 \%$, and $8.6 \%$ respectively. Also no significant difference of these symptoms was found between carrier state and acute typhoid fever ( $\mathrm{p}>0.05)$.

Table 1. The comparison of clinical symptoms between acute and carrier state of typhoid fever

\begin{tabular}{|c|c|c|c|}
\hline \multirow{2}{*}{ Clinical signs } & \multicolumn{2}{|c|}{ State of illness and number (\%) } & \multirow{2}{*}{ OR (95\% CI, P) } \\
\hline & Acute (n=141) & Carriers $(n=46)$ & \\
\hline Coated tongue & 139 (98.5) & $45(97.8)$ & $1.01(0.96-1.06,=0.723)$ \\
\hline Malaise & $141 ;(100.0)$ & $46(100.0)$ & 1 \\
\hline Headache & $132(93.6)$ & $39(84.8)$ & $1.10(0.97-1.26,=0.062)$ \\
\hline Stupor & $21(14.9)$ & $18(39.1)$ & $2.63(1.54-4.48,=0.000)$ \\
\hline Nausea & $19(13.5)$ & $11(23.9)$ & $1.77(0.91-3.45,=0.093)$ \\
\hline Constipation & $8(5.7)$ & $4(8.6)$ & $1.53(0.48-4.86,=0.467)$ \\
\hline Abdominal distention & $8(5.7)$ & $4(8.6)$ & $1.53(0.48-4.86,=0.467)$ \\
\hline Diarrhea & $7(5.0)$ & $8(17.4)$ & $0.29(0.11-0.74,=0.007)$ \\
\hline Melena & $13(9.2)$ & $15(32.6)$ & $3.54(1.82-6.87,=0.000)$ \\
\hline Perforation & $14(9.9)$ & $15(32.6)$ & $3.28(1.27-6.28,=0.000)$ \\
\hline
\end{tabular}

Furthermore, percentage of severe clinical symptoms of stupor, melena and perforation in carriers state more higher significantly compared with in acute typhoid fever (39.1\%, $32.9 \%$ and $32.6 \%$ vs $14.8 \%, 9.2 \%$ and $9.9 \%$ respectively) $(\mathrm{p}<0.05)$. While symptom of diarrhea higher in carriers compared with acute typhoid fever (17.4\% vs $5.0 \%$ ), but no difference significantly in symptom of diarrhea was found between the carrier state and acute typhoid fever $(\mathrm{p}>0.05)$.

Table 2. The comparison of flagelin genes variants between acute and carrier state of typhoid fever

\begin{tabular}{l|c|c|r}
\hline \multirow{2}{*}{ Flagelin gene variants } & \multicolumn{2}{|c}{ State of illness (n; \%) } & \multirow{2}{*}{ OR (95\% CI, P) } \\
\cline { 2 - 3 } $\mathrm{Hd}+$ & Acute (n=141) & Carriers (n=46) & $1.14(0.40-3.30,=0.805)$ \\
$\mathrm{Hj}+$ & $14(9.9)$ & $4(8.7)$ & $3.48(1.12-10.83,=0.014)$ \\
$\mathrm{Hd}+\mathrm{z66+}$ & $32(22.7)$ & $3(6.5)$ & $1.15(0.69-1.94,=0.580)$ \\
$\mathrm{Hj}+\mathrm{z66+}$ & $46(32.6)$ & $4(8.7)$ & $1.23(0.40-3.72,=0.719)$ \\
$\mathrm{Hd}+\mathrm{z66Ind+}$ & $10(7.1)$ & $22(47.8)$ & $1.73(1.16-2.59,=0.011)$ \\
$\mathrm{Hj}+\mathrm{z66Ind+}$ & $39(27.7)$ & 0 & $\mathrm{ND}$ \\
\hline
\end{tabular}




\subsection{The Comparison of Flagellin Genes Variants between Acute and Carrier State of Typhoid Fever}

In Table 2 shows that the percentage of $\mathrm{Hd}^{+}, \mathrm{Hj}^{+}$, $\mathrm{Hd}^{+} \mathrm{z} 66^{+}, \mathrm{Hj}^{+} \mathrm{z} 66^{+}$and $\mathrm{Hd}^{+} \mathrm{z} 66 \mathrm{Ind}^{+}$in acute typhoid fever were found $9.9 \%, 22.7 \%, 32.6 \%, 7.1 \%$ and $27.7 \%$, respectively, while these flagellin genes variants in carrier state were found $8.7 \%, 6.5 \%, 28.3 \%, 8.7 \%$ and $47.8 \%$, respectively. No found flagellin genes variants of $\mathrm{Hj}^{+}$z66Ind ${ }^{+}$in both acute and carrier state of typhoid fever.

Table 3. The relationship clinical signs and flagellin genes in the acute and carriers state of typhoid fever

\begin{tabular}{|c|c|c|c|c|c|c|}
\hline \multirow{2}{*}{ State of illness and clinical signs (n;\%) } & \multicolumn{6}{|c|}{ flagellin genes positive/negative (\% positive) } \\
\hline & $\mathrm{Hd}+$ & $\mathrm{Hj}+$ & $\mathrm{Hd}+\mathrm{z} 66+$ & $\mathrm{Hj}+\mathrm{z66+}$ & Hd+z66Ind+ & $\mathrm{Hj}+\mathrm{z} 66$ Ind + \\
\hline Acute $(n=141)$ & $14 / 127$ (9.9) & $32 / 109$ (22.7) & $46 / 95(32.7)$ & $10 / 131(7.1)$ & $39 / 102(27.6)$ & $0 / 141(0.0)$ \\
\hline Coated tongue (139; 98.5) & $14 / 125(11.2)$ & 30/109 (21.6) & 46/93 (33.1) & $10 / 129(7.2)$ & $39 / 100(28.1)$ & 0/139 (0.0) \\
\hline Malaise $(141 ; 100.0)$ & 14/127 (9.9) & $32 / 109(22.7)$ & 46/95 (32.7) & 10/131 (7.1) & $39 / 102(27.6)$ & $0 / 141(0.0)$ \\
\hline Headache (132; 93.6) & $12 / 120(9.1)$ & $32 / 100(24.2)$ & 43/89 (32.6) & 9/123 (6.8) & 36/96 (27.3) & $0 / 132(0.0)$ \\
\hline Apathy (19; 13.5) & 3/16 (15.8) & $7 / 12(36.8)$ & 2/17 (10.5) & 2/17 (10.5) & 5/14 (26.3) & $0 / 19(0.0)$ \\
\hline Stupor $(21 ; 14.9)$ & 6/15 (28.6) & 2/19 (9.5) & 5/16 (23.8) & 3/18 (14.3) & $5 / 16(23.8)$ & $0 / 21(0.0)$ \\
\hline Nausea (19; 13.5) & $9 / 10(47.4)$ & $6 / 13(31.6)$ & $0 / 19(0.0)$ & $0 / 19(0.0)$ & $4 / 15(21.0)$ & $0 / 19(0.0)$ \\
\hline Constipation $(8 ; 5.7)$ & $5 / 3(62.5)$ & $0 / 8(0.0)$ & $1 / 7(12.5)$ & $0 / 8(0.0)$ & $2 / 6(33.3)$ & $0 / 8(0.0)$ \\
\hline Abdominal distention (8; 5.7) & $5 / 3(62.5)$ & $0 / 8(0.0)$ & $1 / 7(12.5)$ & $0 / 8(0.0)$ & 2/6 (33.3) & $0 / 8(0.0)$ \\
\hline Diarrhea (7; 5.0) & 2/5 (28.6) & 1/6 (14.3) & 1/6 (14.3) & 1/6 (14.3) & $2 / 5(28.6)$ & $0 / 7(0.0)$ \\
\hline Melena (13; 9.2) & 5/8 (38.5) & 2/11 (15.4) & 3/10 (23.1) & $0 / 13(0.0)$ & 3/10 (23.1) & $0 / 13(0.0)$ \\
\hline Perforation $(14 ; 9.9)$ & 8/6 (57.1) & 2/12 (14.3) & 2/12 (14.3) & $0 / 14(0.0)$ & 2/12 (14.3) & $0 / 14(0.0)$ \\
\hline Carriers $(n=46)$ & $4 / 42(8.7)$ & 3/43 (6.5) & 13/33 (28.3) & 4/42 (8.7) & 22/24 (47.8) & $0 / 46(0.0)$ \\
\hline Coated tongue (45; 97.8) & $4 / 41(8.9)$ & $3 / 42(6.7)$ & 13/32 (28.9) & $4 / 41(8.9)$ & $21 / 24(46.7)$ & $0 / 45(0.0)$ \\
\hline Malaise (46; 100.0) & $4 / 42(8.7)$ & $3 / 43(65.2)$ & 13/33 (28.3) & $4 / 42(8.7)$ & $22 / 24(47.8)$ & $0 / 46(0.0)$ \\
\hline Headache (39; 84.8) & 3/36 (7.7) & 3/36 (7.7) & 10/29 (25.6) & 4/35 (10.3) & $19 / 20(48.7)$ & 0/39 (0.0) \\
\hline Apathy (4 ; 8.7) & 1/3 (25.0) & $0 / 4(0.0)$ & $0 / 4(0.0)$ & $0 / 4(0.0)$ & 3/1 (75.0) & $0 / 4(0.0)$ \\
\hline Stupor (18; 39.1) & 3/15 (16.7) & $0 / 18(0.0)$ & $1 / 17(5.5)$ & $0 / 18(0.0)$ & $14 / 4(77.8)$ & $0 / 18(0.0)$ \\
\hline Nausea (11; 23.9) & $4 / 7(36.4)$ & $1 / 10(9.1)$ & $0 / 11(0.0)$ & $0 / 11(0.0)$ & $6 / 5(54.5)$ & $0 / 11(0.0)$ \\
\hline Constipation (4; 8.6) & $2 / 2(50.0)$ & $0 / 4(0.0)$ & $0 / 4(0.0)$ & $0 / 4(0.0)$ & $2 / 2(50.0)$ & $0 / 4(0.0)$ \\
\hline Abdominal distention $(4 ; 8.6)$ & $2 / 2(50.0)$ & $0 / 4(0.0)$ & $0 / 4(0.0)$ & $0 / 4(0.0)$ & $2 / 2(50.0)$ & $0 / 4(0.0)$ \\
\hline Diarrhea $(8 ; 17.4)$ & $3 / 5(37.5)$ & $1 / 7(12.5)$ & $1 / 7(12.5)$ & $1 / 7(12.5)$ & 2/6 (33.3) & $0 / 8(0.0)$ \\
\hline Melena (15; 32.6) & $1 / 14(6.7)$ & $1 / 14(6.7)$ & $0 / 15(0.0)$ & $0 / 15(0.0)$ & $13 / 2(89.7)$ & $0 / 15(0.0)$ \\
\hline Perforation (15; 32.6) & $3 / 12(20.0)$ & $1 / 14(6.7)$ & $0 / 15(0.0)$ & $0 / 15(0.0)$ & $12 / 15(80.0)$ & $0 / 15(0.0)$ \\
\hline
\end{tabular}

\subsection{The Relationship of Clinical Signs and Flagellin Genes between Acute and Carrier State of Typhoid Fever}

The clinical signs of coated tongue, malaise and headache were found most belongs flagellin genes variants of $\mathrm{Hd}^{+} \mathrm{z} 66^{+}(42.7 \%, 33.1 \%$ and $32.7 \%$, respectively) in acute of typhoid fever, while these clinical signs were found less belongs flagellin gens variants of $\mathrm{Hd}^{+} \quad$ (11.2\%, 9.9\% and 9.1\%, respectively). The percentage positive of flagellin genes variants of $\mathrm{Hj}^{+}$and $\mathrm{Hd}^{+}$z66Ind ${ }^{+}$in acute of typhoid fever were found similar in clinical signs of coated tongue, malaise and headache (21.6\%, $22.7 \%$ and $24.2 \%$, respectively vs $28.1 \%$, $27.6 \%$ and $27.3 \%$, respectively) (Table 3 ).

The clinical signs of apathy in acute typhoid fever was found most belongs flagellin genes variants of $\mathrm{Hj}^{+}$ (36.8\%), but less belongs in both flagellin gens variants of $\mathrm{Hd}+\mathrm{z} 66+$ and $\mathrm{Hj}^{+} \mathrm{z}_{66}{ }^{+}$(10.5\%). In contrastly, the clinical signs of stupor was found most belongs flagellin genes variants of $\mathrm{Hd}^{+}, \mathrm{Hd}^{+} \mathrm{z} 66{ }^{+}$and $\mathrm{Hd}^{+} \mathrm{z} 66 \mathrm{Ind}^{+}$(28.6\%, 23.8\% and $23.8 \%$, respectively), but less belongs flagellin genes variants of $\mathrm{Hj}+$ and $\mathrm{Hj}+\mathrm{z} 66^{+}$(9.5\% and $13.3 \%$ ) (Table 3). Furthermore, clinical signs of nausea, constipation, abdominal distention, diarrhea, melena and perforation in acute typhoid fever was found most belongs flagellin genes of $\mathrm{Hd}^{+}$and $\mathrm{Hd}^{+}$z66Ind+ $(47.4 \%, 62.5 \%, 62.5 \%$, $28.6 \%, 38.5$ and $57.1 \%$ vs $21.0 \%$, 33.3\%, 33.3\%, 28.6\%,
$23.1 \%$ and $14.3 \%$, respectively), but these clinical signs was found less belongs $\mathrm{Hj}^{+}$(0.0\%. $0.0 \%, 14.3 \%, 15.4 \%$ and $14.3 \%$, respectively ) except clinical signs of nausea (31.6\%).

Also, the percentage positive of flagellin genes variants of $\mathrm{Hj}^{+} \mathrm{z} 66^{+}$on clinical signs of nausea, constipation, abdominal distention, diarrhea, melena and perforation (0.0\%, $0.0 \%, 0.0 \%, 14.3$ and $0.0 \%$, respectively) were found lower compared with in both percentage positive of flagellin genes variants of $\mathrm{Hd}^{+}$and $\mathrm{Hd}^{+}$z66Ind ${ }^{+}$(Table 3). while percentage positive of flagellin genes variants of $\mathrm{Hd}^{+} \mathrm{z}_{6}{ }^{+}$and $\mathrm{Hd}^{+} \mathrm{z} 66 \mathrm{Ind}^{+}$were found same for clinical signs of melena and perforation in acute typhoid fever. The clinical signs of stupor, melena and perforation in carrier state of typhoid fever were found clearly higher belongs flagellin genes variants of $\mathrm{Hd}^{+} \mathrm{z} 66 \mathrm{Ind}^{+}$(77.8\%, $89.7 \%$ and $80.0 \%$, respectively) compared with other flagellin genes variants (Table 3 ).

\subsection{Severity of Illness Related with Flagellin Genes Variants in Acute and Carriers State of Typhoid Fever}

In Table 4 shows that the severity of illness (ie. stupor, melena and perforation) in carrier state of typhoid fever related with flagellin genes variants especially $\mathrm{Hd}^{+} \mathrm{z} 66 \mathrm{Ind}^{+}$ compared with other flagellin genes variants in acute typhoid fever. 
Table 4. Multivariate analysis: severity of illness related with flagellin genes variants in acute and carriers state of typhoid fever

\begin{tabular}{|c|c|c|c|}
\hline \multirow{2}{*}{ Variable as clinical symptoms and flagellin genes } & \multicolumn{2}{|c|}{ State of illness } & \multirow{2}{*}{ OR $(95 \%$ CI, $P)$} \\
\hline & acute (n) & carrier state (n) & \\
\hline Coated tongue & 139 & 45 & \\
\hline $\mathrm{Hd}+$ & 14 & 4 & $0.87(0.31-2.55,=0.816)$ \\
\hline $\mathrm{Hj}+$ & 30 & 3 & $0.31(0.10-0.96,=0.023)$ \\
\hline $\mathrm{Hd}+\mathrm{z} 66+$ & 46 & 13 & $1.15(0.68-1.92,=0.599)$ \\
\hline $\mathrm{Hj}+\mathrm{z} 66+$ & 10 & 4 & $1.54(0.56-4.28,=0.403)$ \\
\hline Hd+z66Ind+ & 39 & 21 & $0.60(0.40-0.91,=0.020)$ \\
\hline Malaise & 141 & 46 & \\
\hline $\mathrm{Hd}+$ & 14 & 4 & $1.14(0.40-3.30,=0.805)$ \\
\hline $\mathrm{Hj}+$ & 32 & 3 & $0.29(0.09-0.89,=0.014)$ \\
\hline $\mathrm{Hd}+\mathrm{z} 66+$ & 46 & 13 & $1.15(0.69-1.94,=0.580)$ \\
\hline $\mathrm{Hj}+\mathrm{z} 66+$ & 10 & 4 & $0.82(0.27-2.49,=0.729)$ \\
\hline Hd+z66Ind+ & 39 & 22 & $0.58(0.39-0.87,=0.011)$ \\
\hline Headache & 132 & 39 & \\
\hline $\mathrm{Hd}+$ & 12 & 3 & $1.18(0.35-3.98,=0.786)$ \\
\hline $\mathrm{Hj}+$ & 32 & 3 & $0.32(0.10-0.98,=0.024)$ \\
\hline $\mathrm{Hd}+\mathrm{z} 66+$ & 43 & 10 & $1.18(0.65-2.13,=0.572)$ \\
\hline $\mathrm{Hj}+\mathrm{z} 66+$ & 9 & 4 & $0.66(0.22-2.04,=0.476)$ \\
\hline Hd+z66Ind+ & 36 & 19 & $0.56(0.37-0.86,=0.011)$ \\
\hline Apathy & 19 & 4 & \\
\hline $\mathrm{Hd}+$ & 3 & 1 & $0.63(0.09-4.62,=0.658)$ \\
\hline $\mathrm{Hj}+$ & 7 & 0 & $0.47(0.33-0.65,=0.145)$ \\
\hline $\mathrm{Hd}+\mathrm{z} 66+$ & 2 & 0 & ND \\
\hline $\mathrm{Hj}+\mathrm{z} 66+$ & 2 & 0 & ND \\
\hline Hd+z66Ind+ & 5 & 3 & $1.69(0.68-4.25,=0.497)$ \\
\hline Stupor & 21 & 18 & \\
\hline $\mathrm{Hd}+$ & 6 & 3 & $1.71(0.50-5.89,=0.379)$ \\
\hline $\mathrm{Hj}+$ & 2 & 0 & ND \\
\hline $\mathrm{Hd}+\mathrm{z} 66+$ & 5 & 1 & $0.23(0.03-1.82,=0.115)$ \\
\hline $\mathrm{Hj}+\mathrm{z} 66+$ & 3 & 0 & $1.20(0.57-2.53,=0.095)$ \\
\hline Hd+z66Ind+ & 5 & 14 & $3.27(1.46-7.30,=0.000)$ \\
\hline Nausea & 19 & 11 & \\
\hline $\mathrm{Hd}+$ & 9 & 4 & $1.55(0.63-3.78,=0.309)$ \\
\hline $\mathrm{Hj}+$ & 6 & 1 & $0.29(0.04-2.09,=0.160)$ \\
\hline $\mathrm{Hd}+\mathrm{z} 66+$ & 0 & 0 & ND \\
\hline $\mathrm{Hj}+\mathrm{z} 66+$ & 0 & 0 & ND \\
\hline Hd+z66Ind+ & 4 & 6 & $0.46(0.17-1.25,=0.118)$ \\
\hline Constipation & 8 & 4 & \\
\hline $\mathrm{Hd}+$ & 5 & 2 & $1.25(0.41-3.82,=0.678)$ \\
\hline $\mathrm{Hj}+$ & 0 & 0 & ND \\
\hline $\mathrm{Hd}+\mathrm{z} 66+$ & 1 & 0 & ND \\
\hline $\mathrm{Hj}+\mathrm{z} 66+$ & 0 & 0 & ND \\
\hline Hd+z66Ind+ & 2 & 2 & $0.50(0.11-2.35,=0.386)$ \\
\hline Abdominal distention & 8 & 4 & \\
\hline $\mathrm{Hd}+$ & 5 & 2 & $1.25(0.41-3.82,=0.678)$ \\
\hline $\mathrm{Hj}+$ & 0 & 0 & ND \\
\hline $\mathrm{Hd}+\mathrm{z} 66+$ & 1 & 0 & ND \\
\hline $\mathrm{Hj}+\mathrm{z} 66+$ & 0 & 0 & ND \\
\hline Hd+z66Ind+ & 2 & 2 & $0.50(0.11-2.35,=0.386)$ \\
\hline Diarrhea & 7 & 8 & \\
\hline $\mathrm{Hd}+$ & 2 & 3 & $0.76(0.17-3.33,=0.714)$ \\
\hline $\mathrm{Hj}+$ & 1 & 1 & $1.14(0.09-15.08,=0.919)$ \\
\hline $\mathrm{Hd}+\mathrm{z} 66+$ & 1 & 1 & $1.14(0.09-15.08,=0.919)$ \\
\hline $\mathrm{Hj}+\mathrm{z} 66+$ & 1 & 1 & $1.14(0.09-15.08,=0.919)$ \\
\hline Hd+z66Ind+ & 2 & 2 & $1.14(0.21-6.11,=0.875)$ \\
\hline Melena & 13 & 15 & \\
\hline $\mathrm{Hd}+$ & 5 & 1 & $0.17(0.02-1.30,=0.04)$ \\
\hline $\mathrm{Hj}+$ & 2 & 1 & $0.37(0.04-3.55,=0.363)$ \\
\hline $\mathrm{Hd}+\mathrm{z} 66+$ & 3 & 0 & $0.63(0.31-1.27,=0.067)$ \\
\hline $\mathrm{Hj}+\mathrm{z} 66+$ & 0 & 0 & ND \\
\hline Hd+z66Ind+ & 3 & 13 & $3.76(1.36-10.33,=0.000)$ \\
\hline Perforation & 14 & 15 & \\
\hline $\mathrm{Hd}+$ & 8 & 3 & $2.86(0.94-8.66,=0.03)$ \\
\hline $\mathrm{Hj}+$ & 2 & 1 & $2.14(0.22-21.10,=0.500)$ \\
\hline $\mathrm{Hd}+\mathrm{z} 66+$ & 2 & 0 & $0.85(0.54-1.34,=0.129)$ \\
\hline $\mathrm{Hj}+\mathrm{z} 66+$ & 0 & 0 & ND \\
\hline Hd+z66Ind+ & 2 & 12 & $5.69(1.51-20.71,=0.000)$ \\
\hline
\end{tabular}


Using multivariant analysis revealed that clinical signs of stupor in carrier state were found 3.27 times higher belongs flagellin genes variants of $\mathrm{Hd}^{+}$z66 Ind ${ }^{+}$compared with other flagellin genes variants in acute typhoid fever with OR 3.27 (1.46-7.30, p <0.05). Also, the clinical signs of melena and perforation in carrier state of typhoid fever were found 3.76 and 5.69 times higher belongs flagellin genes variants of $\mathrm{Hd}^{+}$z66Ind ${ }^{+}$compared with other flagellin genes variants in acute typhoid fever with OR 3.76 (1.26-10.33, p <0.05) and OR 5.69 (1.51-20.71, p $<0.05)$. Other clinical signs in carrier state of typhoid fever were not different significantly between flagellin genes variants of $\mathrm{Hd}^{+} \mathrm{z} 66 \mathrm{Ind}^{+}$compared with other flagellin genes variants in acute typhoid fever $(p>0.05)$.

\section{Discussion}

The results of this study shows that most of clinical symptoms are coated tongue, malaise and headache in both acute and carriers state of typhoid fever, but no difference significantly in these symptoms was found between the carrier state and acute typhoid patients.

A minority of patients develop complications, the most serious of which is perforation of the gastrointestinal (GI) tract [16-18]. The clinical symptoms as severity of illness like stupor, melena and perforation in carrier state of typhoid fever has related with flagellin genes variants especially $\mathrm{Hd}^{+} \mathrm{z} 66 \mathrm{Ind}^{+}$compared with other flagellin genes variants in acute typhoid fever and the clinical signs of stupor in carrier state were found 3.27 times higher belongs flagellin genes variants of $\mathrm{Hd}^{+}$z66Ind ${ }^{+}$compared with other flagellin genes variants in acute typhoid fever. Also, the clinical signs of melena and perforation in carrier state of typhoid fever were found 3.76 and 5.69 times higher belongs flagellin genes variants of $\mathrm{Hd}^{+}$z66Ind ${ }^{+}$compared with other flagellin genes variants in acute typhoid fever. Other clinical signs in carrier state of typhoid fever were not different significantly between flagellin genes variants of $\mathrm{Hd}^{+}$z66Ind ${ }^{+}$compared with other flagellin genes variants in acute typhoid fever.

Several studies suggested that flagellin genes variants of $\mathrm{Hj}^{+}$association of decreased severity of illness, motility and invasiveness of bacteria and compared with flagellin genes variants of $\mathrm{Hd}^{+}[10]$ and flagellin genes variants of z66Ind $^{+}$might seems related with severity of illness of typhoid fever [19]. It is supported by our results that flagellin genes variants of $\mathrm{Hd}^{+} \mathrm{z} 66 \mathrm{Ind}^{+}$have strong related with severity of illness in carrier state of typhoid fever. We need more study to identify flagellin genes variant of $\mathrm{Hd}^{+}$z66Ind ${ }^{+}$from S. typhi for future focused research in chronic carriage in the gall bladder of typhoid patients.

\section{Acknowledgments}

We are grateful to all participants of this study for their voluntary cooperation. We thank the staff from the hospitals and health centers and hospitals in Palu and Central Sulawesi province for their enthusiastic support of the study. We are indebted to the heads of District Health Departments in Central Sulawesi, Dr. Agnes, Dr. Syamsul Rizal, Dr. Irene,Mr.Ali Rotib, Mr. Hamid, Mrs.Rini, Mrs. Ina, Zr. Etty, Mrs. Eka, Mrs. Purwaningsih, Mr. Markus, and Mr. Mus Jubaru for dedicating their precious time to the supervision of clinical and laboratory examinations. Finally, we thank Mr.Romi Usman, Mr. Marwani, Mr. Syafri, and Mr. Rochmat of the Hasanuddin University for their dedicated contributions to the field work activities and performing the blood cultures and sample preparations for molecular testing.

\section{Potential Conflicts of Interest}

All authors: no conflict.

\section{Authors' Contributions}

MS, RD, ARS and MH conceived and designed the experiments. MS, ARS, RD, AF, NT, YD, MA, MRP, NIP, and MH carried out the molecular biology studies. MS, RD, AF, MRP, ARS and MM performed data and specimens collection and also epidemiology, clinical and microbiology results analysis. MS, ARS, RD and $\mathrm{MH}$ participated in the wrote the paper. All authors read and approved the final manuscript.

\section{References}

[1] Mochammad Hatta, Andi R. Sultan, Rob Pastoor, Henk L. Smits: New Flagellin Gene for Salmonella enterica serovar Typhi from the East Indonesian Archipelago: Am J. Trop Med and Hyg 2011, 84: 429-434.

[2] David B Huang, Herbert L DuPont. Problem pathogens: extraintestinal complications of Salmonella enterica serotype Typhi infection. Lancet Infect Dis 2005, 5: 341-348.

[3] Lai CW, Chan RC, Cheng AF, Sung JY, Leung JW: Common bile duct stones: A cause of chronic salmonellosis. Am J Gastroenterol 1992, 87: 1198-1199.

[4] Levine MM, Black RE, Lanata C: Precise estimation of the numbers of chronic carriers of Salmonella typhi in Santiago, Chile, an endemic area 1982, J Infect Dis 146:724-726.

[5] Aldridge P.: Regulation of flagellar assembly. Current Opinion in Microbiology 2002, 5: 160-165.

[6] Harshey R. and Toguchi A.: Spinning tails: homologies among bacterial flagellar systems. Trends in Microbiology 1996, 4: 226231.

[7] Simon M., Zieg J., Silverman M., Mandel G., Doolittle R.: Phase variation: evolution of a controlling element. Science 1980, 209: 1370-1374.

[8] Kutsukake K. and Iino T.: A trans-acting factor mediates inversion of a specific DNA segment in flagellar phase variation of Salmonella. Nature 1980, 284: 479-481.

[9] Mortimer C., Gharbia S., Logan J., Peters T. and Arnold C.: Flagellin gene sequence evolution in Salmonella Infection, Genetics and Evolution 2007, 7: 411-415.

[10] Grossman, D. A., N. D. Witham, D. H. Burr, M. Lesmana, F. A. Rubin, G. K. Schoolnik, and J. Parsonnet: Flagellar serotypes of Salmonella typhi in Indonesia: relationships among motility, invasiveness, and clinical illness. J. Infect. Dis 1995, 171: 212-216.

[11] Mochammad Hatta and Henk L Smits: Detection of Salmonella typhi by nested Polymerase Chain Reaction in blood, urine and stool samples. Am J. Trop Med Hyg 2007, 76; 139-143.

[12] Cruickshank R,: Medical Microbiology: A Guide to the Laboratory Diagnosis and Control of Infection, Edinburgh: E \& $S$ Livingstone Ltd. 1968.

[13] Miller SI, Hohmann EL, Pegues DA.:Salmonella (including Salmonella Typhi). In: Mandell GL, Bennet JR, Dolin R, eds. Principles and practice of infectious diseases. New York: Livingstone 1994: 2013-33.4.

[14] Baker S, Holt K, van de Vosse E, Roumagnac P, Whitehead S, King E, Ewels P, Keniry A, Weill FX, Lightfoot D, van Dissel JT, Sanderson KE, Farrar J, Achtman M, Deloukas P, Dougan G: 
High throughput genotyping of Salmonella enteric serovar Typhi allowing geographical assignment of haplotypes and pathotypes within an urban District of Jakarta, Indonesia. J Clin Microbiol 2008, 46: 1741-6.

[15] Huang X, Phungle V, Dejsirilert S, Tishyadhigama P, Li Y, Liu H, Hirose K, Kawamura Y, Ezaki T: Cloning and characterization of the gene encoding the z66 antigen of Salmonella enteric serovar typhi. FEMS Microbiol Lett 2004, 234: 239-246.

[16] van Basten JP, Stockenbrugger R.: Typhoid perforation: a review of the literature since 1960. Trop Geogr Med 1994, 46: 336-339.

[17] Butler T, Knight J, Nath SK, Speelman P, Roy SK, Azad MAK.: Typhoid fever complicated by intestinal perforation: a persisting fatal disease requiring surgical management. Rev Infect Dis 1985, 7: 244-256.

[18] Bitar R, Tarpley J.: Intestinal perforation in typhoid fever: a state of the art review. Rev Infect Dis 1985, 7: 257-271.

[19] Mochammad Hatta, Rob Pastoor, Pauline FD Scheelbeck, A.R. Sultan, Ressy Dwiyanti, Ibrahim Labeda, H.L. Smits: Multi-Locus Variable-Number Tandem Repeat Profiling of Salmonella enterica Serovar Typhi Isolates from Blood Cultures and Gallbladder Specimens from Makassar, South-Sulawesi, Indonesia. PloS ONE 2011, 6 (9): 1-11. 